\title{
Knowledge Health Care and Practice of Physicians, Nurses and Traditional Providers about Hepatitis C Virus Infection in Six Egyptian Governorates
}

\author{
Ahmed E. Shoman*, Somaia I. Salama**, Amany Mohamed Sayed*, Amira \\ Mohsen**, Waleed Salah Eldin*, Asmaa M. Fathy**, Walaa A. Fouad**, \\ Ammal M. Metwally** \\ *Department of Community, Environmental and Occupational Medicine, Faculty of \\ Medicine, Ain Shams University \\ ** Department of Community Medicine, National Research Centre
}

\begin{abstract}
Background: Hepatitis $\mathrm{C}$ is a major health problem in Egypt, with 8 out of each 10 new cases occurs in hospitals. Health care workers are at high risk of contracting hepatitis $\mathrm{C}$ and transmitting it to their patients.

Objective: The aim of the study was to assess the knowledge of health care workers about hepatitis $\mathrm{C}$ virus infection transmission and prevention.

Methods: A descriptive cross sectional survey was conducted in six Egyptian governorates including randomly selected physicians, nurses and traditional providers. An interview questionnaire was conducted to HCWs to assess their sociodemographic characteristics, knowledge about cause of HCV, symptoms, transmission and prevention. An observational checklist was designed to assess infection control practices of physicians and nurses.

Results: Mean knowledge score of physicians was (36 \pm 5.6 ) out of 44 with mean practice score $(5 \pm 3.9)$ out of 9 . The mean knowledge score of nurses was $(29.6 \pm 6.2)$ out of 41 and mean practice score $(3.49 \pm 3.5)$ out of 7 , while the knowledge score of the traditional providers was $25.9 \pm 5.8$ out of 40 . The knowledge and practice score were positively correlated with attendance of infection control courses. Correct knowledge about contaminated needles as a mode of transmission was $93.7 \%$ for physicians, $72.7 \%$ for nurses, and 3\% for traditional providers. There was statistically significant difference between the groups regarding knowledge score with the traditional providers having the lowest knowledge.
\end{abstract}

Conclusion: The percentage of correct knowledge was higher among physicians than nurses, while the traditional providers had the lowest knowledge, with some gaps which need to be strengthened through infection control courses.

Key words: hepatitis C, knowledge, practice, physicians, nurses, traditional providers, Egypt.

\section{Introduction}

Hepatitis $\mathrm{C}$, the silent epidemic, is a serious health problem and one of the most important leading causes of death worldwide (1).

WHO estimates that about 130-150 million people, $3 \%$ of the world's population, are infected with $\mathrm{HCV}$ and
3-4 million persons are newly infected each year (2).

Approximately 350,000 to 500,000 people die every year from hepatitis Crelated liver disease (3). 
Egypt has higher rates of $\mathrm{HCV}$ infections than neighboring countries with comparable socioeconomic conditions and hygienic standards for invasive medical, dental, or paramedical procedures. Hepatitis $\mathrm{C}$ kills an estimated 40,000 Egyptians every year (3). Residents of Egypt's Nile River Delta are among the world's highest seroprevalence of hepatitis $\mathrm{C}$ virus (HCV) infection with very serious impact of $\mathrm{HCV}$ on chronic liver disease (4). The HCV transmission is ongoing in Egypt and incidence rates have been estimated as 165,000 new infections annually (5). Transmission can occur through medical procedures; such as transfusion of non-screened blood, reuse of inadequately sterilized needles, syringes or other medical equipment or through needle-sharing among drug-users. Other modes of transmission done by traditional providers include social, cultural and behavioral practices, using percutaneous procedures (6). There are some emerging risky behaviors usually occurs in Egyptian families and may lead to spread of infection; such as sharing the same loofah, scarves' pins, same syringe for insulin injections (7).

Hepatitis $\mathrm{C}$ can be spread in clinical settings from patient to patient, from patient to doctor, and from doctor to patient which leads to 8 out of 10 new infections occurring in hospitals and clinics (3). That fact reveals the great role of health care providers in transmission of $\mathrm{HCV}$.

Having enough knowledge about $\mathrm{HCV}$ infection among the health care workers is the cornerstone of preventing the spread of HCV. While, the lack of knowledge and awareness about Hepatitis $\mathrm{C}$ in the community often leads to misinformation, missing of early opportunities for prevention and treatment, and stigmatization of infected populations in the work place, by family members and by members of their communities. The consequences for members of atrisk communities are dangerous; because missing these opportunities for prevention can lead to infection of additional people with $\mathrm{HCV}(\mathbf{8 , 9})$.

Confirmed transmission of $\mathrm{HCV}$ in health care facilities, in addition to the factor that many infected patients are unaware of their status, all raise concerns related to the need to assess the knowledge status of the health care providers about modes of transmission of $\mathrm{HCV}$ and ways of prevention and their practical adherence to infection control guidelines.

\section{Objective of the study}

To measure knowledge of governmental medical health care providers (physicians and nurses) and paramedical traditional staff (midwives, technicians) about $\mathrm{HCV}$ infection in Egypt.

\section{Subjects and Methods}

Study design: Descriptive study. Study population: Health care providers including 130 physicians, 143 nurses, and 133 traditional staff (Midwives, technicians). Study site: Health care facilities in six Egyptian governorates including Cairo, Benisuief, Assuit, El Garbyia, El Dakahlya, and Red sea. Study duration: from August 2014 to May 2015. Sampling technique: multistage random sampling Sample size: Sample size for a cluster sample $=$ Simple Random Sample size $\mathrm{x}$ Design effect. The design effect $=(1+\quad(m-1) \quad p) \quad$ where $\mathrm{m}=$ size of the cluster and $\mathrm{p}=$ intracluster correlation coefficient (ICC), the estimated $95 \%$ confidence interval is $0.2-0.8$, the sample size for Simple Random Sample equals 43, If the average cluster size is 3 and assuming 
a high ICC of 0.9 , we will have a design effect of 3 . The sample size of each group after correction is approximately 130 individuals. Study tools: Three Interview questionnaires were designed to detect knowledge of the physicians, nurses and traditional staff concerning etiology of $\mathrm{HCV}$, symptoms, modes of transmission and prevention. Two observational checklists were prepared for the physicians and nurses to assess their adherence to some infection control guidelines. Both the questionnaire and the checklist were prepared by the research team after literature review guided by $\mathrm{CDC}$ recommendations for prevention and control of Hepatitis $\mathrm{C}$ virus (HCV) infection and $\mathrm{HCV}$ related chronic disease (10).

Data analysis: After data cleaning, the statistical package of social sciences (SPSS-18) was used for data processing. Descriptive statistics was done for data summarization in the form of frequency and percentage for qualitative variables and means \pm SD for quantitative variables. Scoring of knowledge and practice was done by giving the correct answer one point and the incorrect answer zero point, the total knowledge and practice scores were calculated by adding the scores of all items. The overall score was calculated by adding the knowledge and practice scores. Inferential statistics was done for comparing the participant groups using chi square test for qualitative data, ANOVA test and student's $t$ test for parametric quantitative data, Mann whitney test and Kruskal wallis for non parametric quantitative data, With $\mathrm{p}$ value $<0.05$ considered significant, $\mathrm{p}$ value $<0.01$ considered highly significant.

Ethical consideration: Informed consents were obtained from all participants. Approval of the research protocol was taken from the ethical committee of the Faculty of Medicine, Ain Shams University and the ethical committee of the National Research Centre.

\section{Results}

The present study showed that the sociodemographic characteristics of the three groups were as following: The mean age was $(34 \pm 9.4)$ for the physicians, $(33 \pm 10)$ for the nurses, and $(38.5 \pm 6.8)$ for the traditional providers. $71.5 \%$ of physicians were male, and about $96 \%, 86 \%$ of the nurses and traditional providers respectively were females. Around $75 \%$ and $67 \%$ of physicians and nurses respectively attended infection control courses (Table 1).

As regard general knowledge, Around 93\% of the participant physicians, $90 \%$ of nurses, with less percentage $(80 \%)$ for the traditional providers knew that hepatitis $\mathrm{C}$ can be prevented, Around $92 \%$ of the physicians, $63 \%$ of nurses, and $53 \%$ of traditional providers knew that hepatitis $\mathrm{C}$ has no vaccination. Results of knowledge about etiology of $\mathrm{HCV}$ showed that physicians had the best knowledge (100\%) followed by the nurses $(94 \%)$ then the traditional providers had the least knowledge (74\%). Knowledge about population at risk revealed that medical workers have the highest risk according to $97 \%$ of physicians, $91 \%$ of nurses, and $83 \%$ of traditional providers (Table 2)

Regarding knowledge about modes of transmission, around $81 \%$ of the physicians considered injectable drug addiction as a major way of transmission of $\mathrm{HCV}$, but only $1.4 \%$ of nurses and $4 \%$ of traditional providers agreed with that. Around $99 \%$ of physicians, $98 \%$ of nurses, and $86 \%$ of traditional providers knew that contaminated blood transfusion is a method of HCV transmission. In the present study Around $89 \%$ of 
physicians, $77 \%$ of nurses, and $74 \%$ of traditional providers knew that razors can be a possible way of transmission. Around $79 \%$ of physicians, 59\% of nurses, and $51 \%$ of traditional providers knew that $\mathrm{HCV}$ can be transmitted from mother to the fetus. Around $94 \%$ of physicians, $72 \%$ of nurses, and only $3 \%$ of traditional providers knew that contaminated tools transmit HCV. Around $94 \%$ of the physicians, $62 \%$ of nurses and $58 \%$ of traditional providers considered people who had renal dialysis or organ transplantation are at increased risk of infection with HCV (Table 3).

Concerning HCWs' knowledge about ways of prevention, Around $99 \%$ of physicians, $78 \%$ of nurses, and $71 \%$ of traditional providers realized the importance of infection control guidelines during blood transfusion. Around $95 \%$ of physicians, $94 \%$ of nurses, and $87 \%$ of traditional providers knew that washing hands after removing gloves is an infection control guideline. $100 \%$ of physicians, $99 \%$ of nurses and around $92 \%$ of traditional providers knew the necessity of using sterilized instruments for each patient. Around $99 \%$ of physicians, $97 \%$ of nurses, and $84 \%$ of traditional providers realized the importance of availability of certain equipments to prevent $\mathrm{HCV}$ transmission. Around $85 \%$ of physicians, $58 \%$ of nurses, and $52 \%$ of traditional providers knew that avoiding suspicious sexual relationships is a way of prevention of HCV (Table 3).

Generally, there was statistically significant association between knowledge and practice score of the participants and their age, years of experience, and attendance of infection control course $\quad(p<0.05)$, the participants who attended infection control courses had better knowledge than who didn't attend it (Table 6,7).

\section{Discussion}

In the present study, Around 93\% of the participant physicians, $90 \%$ of nurses, and $80 \%$ of the traditional providers knew that hepatitis $\mathrm{C}$ can be prevented. The percentages of the physicians and nurses agreed to some extent with the results of Yaghi study (2) who conducted a cross-sectional survey including all health care workers (physicians, nurses, pharmacists and laboratory technicians) in 92 primary health care centers in Kuwait, and reported that $90 \%$ of physicians, nurses and paramedical staff agreed that the protection from being infected with hepatitis $\mathrm{C}$ can be done using infection control guidelines. However, the percentage of the traditional providers was lower than the results of Yaghi study. The possible reason of that difference may be that the traditional providers in the present study didn't attend any infection control courses unlike the physicians and nurses.

In the current study, physicians had the best knowledge about the cause of hepatitis C (100\%) followed by the nurses $(94 \%)$ then the traditional providers had the least correct knowledge (74\%). These percentages are higher than the results of Van de Mortel study (11) who conducted a cross sectional study among Australian physicians, nurses and paramedical staff and reported that $72 \%$ of them knew that hepatitis $\mathrm{C}$ is caused by a virus. The possible cause of that difference is that $43 \%$ of the participants in de Mortel study were younger than 30 years old, while the mean age of the participants in the present study were $(34 \pm 9.4)$ years for the physicians, $(33 \pm 10)$ years for the nurses, and (38.5 \pm 8.6$)$ years for the traditional providers, and their age reflected on their years of experience. The study of De Villiers (12) revealed that health care workers are at 
increased risk of blood borne diseases including HCV. In the current study, around $97 \%$ of the physicians, $91 \%$ of nurses, and $83 \%$ of traditional providers reported that medical workers have high risk to be infected with HCV. These percentages are higher than results of the kuwatian study (2) which reported that $74 \%$ of the physicians, nurses, and paramedical staff considered health care workers at high-risk population. The possible reason for this difference may be the higher perception of risk and fear of $\mathrm{HCV}$ infection among Egyptian health care workers as HCV is epidemic in Egypt, and Egypt has the highest prevalence of $\mathrm{HCV}$ worldwide (3).

The results of the present study showed that around $94 \%$ of the physicians considered people who had renal dialysis are at increased risk of infection with HCV. That percentage is higher than the results of Ferrante study (13) who reported that $69 \%$ of family physicians agreed with that. However, only $62 \%$ of nurses and $58 \%$ of traditional providers in the current study considered that dialysis increases risk of $\mathrm{HCV}$ infection. These results are lower than the results of Bianco study (14) who conducted a crosssectional survey including all nurses in 37 hemodialysis units in Italy, and reported that $93 \%$ of Italian nurses considered organ transplantation and hemodialysis as a source of infection. That difference may be due to that the nurses in Bianco study were all working in hemodialysis unit, with higher knowledge about that mode of transmission of HCV.

Regarding modes of transmission of $\mathrm{HCV}$; around $99 \%$ of physicians, $98 \%$ of nurses, and $86 \%$ of traditional providers knew that contaminated blood transfusion is a method of HCV transmission. These results are higher than the results of Yaghi study (2) who found that $92 \%$ of physicians, nurses, and paramedical staff had correct knowledge about blood and blood products. The reason of this difference may be due to strict regulation of the Egyptian Ministry of Health on the process of safe blood transfusion. However, the results of the current study agreed with a study done in Kuwait by Alkandari (15) who reported that most of the primary health care workers were aware that blood and blood products are the main routes of transmission of $\mathrm{HCV}$.

Regarding razors and toothbrushes as a way of transmission of $\mathrm{HCV}$, In the present study around $89 \%$ of physicians knew that razors and toothbrushes are ways of $\mathrm{HCV}$ transmission, these results agree to some extent with results of Ferrante study (13) who reported that $86 \%$ of American family physicians recognized that mode of transmission. However, around $77 \%$ of nurses, and $74 \%$ of traditional providers in the present study knew that razor is a way of transmission. These percentages are less than the result of Bianco study (14) who found that $92 \%$ of Italian nurses knew that sharing razors or toothbrushes are way of transmission of $\mathrm{HCV}$. The possible reason of this difference may be due to the lower awareness about that mode of transmission in Egypt than Italy, As the infection control courses in Egypt focus on the modes of $\mathrm{HCV}$ transmission within the health care settings not the community based modes of transmission.

Regarding infection control guidelines on blood transfusion, the majority of the participant physicians (99\%), nurses $(78 \%)$, and traditional providers $(71 \%)$ realized the importance of infection control guidelines during blood transfusion, these percentages are higher than the results of Kabinda 
study (16) who conducted a cross sectional study to assess knowledge, attitude and practice of the doctors, nurses, and midwives from 12 general reference hospitals, 11 hospitals and 65 health centers in Congo, and found that $60 \%$ of them knew the ultimate control measures before blood transfusion. The possible cause of this difference may be due to the difference in the experience duration and age between the participants in the two studies.

The results of the current study showed that around $96 \%$ of physicians considered wearing gloves as an important infection control measure, and about $98 \%$ of physicians agreed with changing gloves after dealing with every patient or when torn off, which agree to some extent to the levels in the United States, as 99\% of health care workers agreed with using gloves for incision and for drainage procedures according to the study of Ellison (17). Similarly, health care workers in Canada reported a high rate of wearing gloves when examining patients according to the study of Parker and Goldman (18) However, the results of the present study are higher than the results of Yaghi study (2) who found that $80 \%$ of the physicians, nurses and paramedical staff believed in wearing gloves, and also higher than the results of Rasslan study (19) who conducted a cross sectional study among 404 physicians, nurses and technicians in Ain Shams University hospitals and reported that 93\% of them knew the importance of wearing gloves. This high percentage of correct knowledge may be due to high attendance to infection control courses among the physicians and nurses of the present study. Therefore, training courses play an important role in improving the knowledge of health care workers.

Regarding washing hands after wearing gloves, around $95 \%$ of physicians, $94 \%$ of nurses, and $87 \%$ of traditional providers knew that washing hands after removing gloves is an infection control guideline. These results are higher than the results of Tobin study (20) who found that the correct knowledge about washing hands after removing gloves among Nigerian medical and paramedical health care providers was $73 \%$. The possible cause of that difference may be due to that the participants in the current study had longer experience than Tobin study. As around 50\% of the participants in the current study had experience more than 5 years, while in Tobin study $71 \%$ of the participants had experience less than 5 years. In the current study $100 \%$ of physicians, $99 \%$ of nurses, and $91 \%$ of traditional providers knew the importance of hygienic guidelines after any skin cut. The percentages of the physicians and nurses are higher than the results of Al-Dabbas \& AbuRmeileh study (21) who found that $96 \%$ of Palestinian medical health care workers agreed to follow certain precautions for wound suturing. The possible cause of that difference may be the unavailability of the equipment and tools needed for these hygienic precautions in Palestine.

Regarding the total knowledge score, there was statistically significant difference between the three groups regarding knowledge score $(\mathrm{p}<0.05)$ with the physicians had the highest percentage of correct knowledge while the traditional providers had the lowest percentage of correct knowledge. These results agree with the results of Joukar study (1) who found statistically significant difference between the doctors, nurses, and paramedical staff. Regarding the observational practice score of the physicians and the nurses, there was statistically significant difference between the physicians and nurses 
regarding the total practice score $(p<0.05)$ with the physicians had higher percentage of correct practice than the nurses. These results agree with the results of Setia study (22) who reported that there was significant difference between the physicians and nurses regarding total practice score.

In the current study, there was a statistically significant association between knowledge of the participants and their age, years of experience, and attendance of infection control course $(p<0.05)$. There was statistically significant association between practice score of the physicians and nurses and their age, years of experience, and attendance of infection control course $(p<0.05)$. These results agree with the results of Richmond study (23) who conducted a cross sectional study among 3675 Australian complementary therapists, dentists, medical practitioners, nurses, pharmacists, and reported that older age and longer experience of health care workers was associated with greater knowledge.

\section{Conclusion and Recommendations}

Knowledge of the physicians was better than the nurses' knowledge with the traditional providers had the least knowledge with important gaps which should be strengthened. It is recommended to develop continuous education programs and training courses about infection control measures for health care providers, to improve their knowledge and promote their performance especially the traditional providers.

\section{References}

1) Joukar F, Mansour-Ghanaei F, Soati F and Meskinkhoda P (2012): Knowledge levels and attitudes of health care professionals toward patients with hepatitis $\mathrm{C}$ infection. W J Gastroenterology; 18(17): 3844.

2) Yaghi $\mathbf{S}$ A, btihal Al-Habib $\mathbf{E}$ S, Lia S A, Almutairi $\mathbf{G} \mathbf{R}$, Makboul G, and El-Shazly $M$ K (2012): Knowledge, attitude, and behavior of primary health care workers about hepatitis C, Kuwait. Greener J Med Sci; 2 (4): 8491.

3) World health organization (2015): Hepatitis C fact sheets; http://www.who.int/media centre /factsheets/fs164/en/

4) Darwish M A, Faris R, Darwish N, Shouman A, Gadallah M, El-Sharkawy M S, Edelman R, Grumbach K, Rao M R and Clemens J D (2001): Hepatitis $c$ and cirrhotic liver disease in the Nile delta of Egypt: a community-based study. Am J Trop Med Hyg; 64 (3):147-153.

5) Mostafa A, Taylor S, El-Daly $M$, et al. (2010): Is the hepatitis $\mathrm{C}$ virus epidemic over in Egypt? Incidence and risk factors of new hepatitis $\mathrm{C}$ virus infections. Liver Int; 31(4): 560-566.

6) Kabir A, Tabatabaei $\mathbf{S}$ and Khaleghi S (2010): Knowledge, attitudes and practice medical specialists regarding hepatitis $\mathrm{B}$ and $\mathrm{C}$. Hepat Man; 10(3):176-182.

7) Metwally A M, Mohsen A, Saleh R, Foaud W, Ibrahim N, Rabaah T, and El-Sayed $M$ (2014): Prioritizing HighRisk Practices and Exploring New Emerging Ones Associated With Hepatitis C Virus Infection in Egypt. Iranian J Publ Health; 43(10): 1385-1394. 
8) Ball J, and Pike G (2008) Needle stick injury in 2008 Result from a survey of RCN members. London: Royal College of Nursing.

9) Basal A, Kamel E, and Nafady H (2011): Studying the Quality of Life of Chronic Hepatitis C Patients and the Associated Factors, J Am Sci.,7(12):649-655.

10) Centers for disease control and prevention (1998): Recommendations for Prevention and Control of $\mathrm{C}$ Virus (HCV) Infection and HCV-Related Chronic Disease; http://www.cdc.gov/mmwr/pre view/mmwrhtml/00055154.htm

11) Van de Mortel T F (2002): Health Care Workers' Knowledge and Attitudes toward Hepatitis C Patients with Hepatitis C: A pilot Study. Aust J Adv Nur; 20(1): 13-19.

12) De Villiers $\mathbf{H ~ C}$, Nel $M$ and Prinsloo E (2007): Occupational exposure to blood borne viruses amongst medical practitioners in Bloemfontein, South Africa. SA Family Practice; 49(3):14-20

13) Ferrante J M, Winston $\mathbf{D}$ G, Chen $P$ H and de la Torre A N (2008): Family physicians' knowledge and screening of chronic hepatitis and liver cancer. Fam med; 40(5): 345350.

14) Bianco A, Bova F, Nobile $C$ G, Pileggi $C$ and Pavia $M$ (2013): Healthcare workers and prevention of hepatitis $\mathrm{C}$ virus transmission: exploring knowledge, attitudes and evidence-based practices in hemodialysis units in Italy. BMC infectious disease; 13(1): 76-80.
15) Alkandari A, Aljodarb S, Albahhouh H A, Makboul G and El-Shazly $M$ (2013): Knowledge, Attitudes and SelfReported Behavior of Primary Health Care Workers for Hepatitis B and C Virus and other Health Care Associated Infection. Greener J Med Sci.; 3(1): 18- 31.

16) Kabinda J M, Miyanga SA, Donnen P, Van den Ende J and Dramaix $M$ W (2014): Knowledge, Attitudes and Practices of Medical and Paramedical Staff in Blood Transfusion in the Democratic Republic of Congo. Open J Prev Med; 4(1): 672680.

17) Ellison A M, Kotelchuck $\mathbf{M}$ and Bauchner $H$ (2007): Standard precautions in the pediatric emergency department: knowledge, attitudes, and behaviors of pediatric and emergency medicine residents. Pediatr Emerg Care; 23(1): 877-880.

18) Parker MJ and Goldman RD (2006): Paediatric emergency department staff perceptions of infection control measures against severe acute respiratory syndrome. Emerg Med J; 23(2): 349-353.

19) Rasslan O, Salama S, Aboul Fotouh A, Salama I and Dewedar S (2011): Safe injection practices among Health-Care Workers in Ain Shams University hospitals. MSC thesis: Faculty of Medicine. Ain Shams University.

20) Tobin E A, Asogun D A, Odia I and Ehidiamhen G (2013): Knowledge and practice of infection control among health workers in a tertiary hospital in 
Edo state, Nigeria. Direct Res J Health Pharm; 1(2): 20-27.

21) Al-Dabbas $M$ and AbuRmeileh N (2012): Needlestick injury among interns and medical students in the Occupied Palestinian Territory. EMHJ; 18(7): 700-706.

22) Setia S, Gambhir R, Kapoor $V$, Jindal $G$ and Garg $S$ (2014): Attitudes and Awareness Regarding Hepatitis
B and Hepatitis C Amongst Healthcare Workers of a Tertiary Hospital in India. Annals of Med and Health Sci Res; 3(4): 551-558.

23) Richmond J, Dunning $\mathbf{T}$ and Desmond $P$ (2007): Health professionals' attitudes toward caring for people with hepatitis C. J Vir Hepatitis; 14(9): 624632. 
Table 1: Distribution of the Participants according to their Socoiodemographic Characteristics

\begin{tabular}{|c|c|c|c|c|c|c|}
\hline & \multicolumn{2}{|c|}{$\begin{array}{l}\text { Physicians } \\
(\mathrm{N}=130)\end{array}$} & \multicolumn{2}{|c|}{$\begin{array}{l}\text { Nurses } \\
(\mathrm{N}=143)\end{array}$} & \multicolumn{2}{|c|}{$\begin{array}{l}\text { Traditional providers } \\
(\mathrm{N}=133)\end{array}$} \\
\hline $\begin{array}{l}\text { Age in years } \\
\text { (Mean } \pm \text { SD) }\end{array}$ & \multicolumn{2}{|c|}{$34 \pm 9.4$} & \multicolumn{2}{|c|}{$33 \pm 10$} & \multicolumn{2}{|c|}{$38.5 \pm 6.8$} \\
\hline Variable & $\mathrm{N}$ & $\%$ & $\mathrm{~N}$ & $\%$ & $\mathrm{~N}$ & $\%$ \\
\hline \multicolumn{7}{|l|}{ Gender } \\
\hline Male & 93 & 71.5 & 6 & 4.2 & 42 & 31.6 \\
\hline Female & 37 & 28.5 & 137 & 95.8 & 91 & 68.4 \\
\hline \multicolumn{7}{|l|}{ Residence } \\
\hline Cairo & 28 & 21.5 & 42 & 29.3 & 9 & 6.8 \\
\hline El Dakahlya & 22 & 16.9 & 32 & 22.4 & 36 & 27.1 \\
\hline \multirow{2}{*}{$\begin{array}{l}\text { El Garbyia } \\
\text { Assuit }\end{array}$} & 23 & 17.7 & 30 & 21.0 & 35 & 26.3 \\
\hline & 25 & 19.3 & 4 & 2.8 & 26 & 19.5 \\
\hline Beni-suief & 18 & 13.8 & 21 & 14.7 & 25 & 18.8 \\
\hline Red sea & 14 & 10.8 & 14 & 9.8 & 2 & 1.5 \\
\hline \multicolumn{7}{|c|}{ Experience in years } \\
\hline$<1$ year & 15 & 11.5 & 9 & 6.3 & 9 & 6.8 \\
\hline $1-5$ years & 51 & 39.3 & 38 & 26.6 & 41 & 30.8 \\
\hline$>5$ years & 64 & 49.2 & 96 & 67.1 & 83 & 62.4 \\
\hline \multicolumn{7}{|c|}{ Attend infection control course } \\
\hline Yes & 98 & 75.4 & 96 & 67.1 & & \\
\hline No & 32 & 24.6 & 47 & 32.9 & & \\
\hline
\end{tabular}


Table 2:Comparison between Physicians, Nurses and Traditional Providers regarding their Correct Knowledge about Main Organ Affected, Population at Risk and Symptoms of HCV:

\begin{tabular}{|c|c|c|c|c|}
\hline & $\begin{array}{l}\text { Physicians } \\
(\mathrm{N}=130)\end{array}$ & $\begin{array}{l}\text { Nurses } \\
(\mathrm{N}=143)\end{array}$ & $\begin{array}{l}\text { Traditional } \\
\text { providers } \\
(\mathrm{N}=133)\end{array}$ & $\mathrm{x}^{2}$ \\
\hline Variable & N. $(\%)$ & N. $(\%)$ & N. $(\%)$ & $\mathrm{P}$ value \\
\hline \multicolumn{5}{|c|}{ Main organ affected by hepatitis $\mathrm{C}$ infection } \\
\hline Liver & $123(94.6)$ & $130(90.9)$ & $108(81.2)$ & $.002 *$ \\
\hline Blood & $118(90.8)$ & $122(85.3)$ & $124(93.2)$ & .086 \\
\hline Other organs & $129(99.2)$ & $140(97.9)$ & $127(95.5)$ & .138 \\
\hline Hepatitis $\mathrm{C}$ can be prevented & $121(93.1)$ & $129(90.2)$ & $107(80.2)$ & .109 \\
\hline Hepatitis C has a vaccine & $120(92.3)$ & $90(62.9)$ & $71(53.4)$ & $.001 *$ \\
\hline \multicolumn{5}{|c|}{ People at risk of infection by HCV: } \\
\hline 1 - Medical workers & $126(96.9)$ & $130(90.9)$ & $110(82.7)$ & $.001 *$ \\
\hline $2-$ Workers at dental clinics & $117(90)$ & $108(75.5)$ & $98(74)$ & $.006 *$ \\
\hline $\begin{array}{l}3 \text { - People who need blood } \\
\text { transfusions or renal dialysis }\end{array}$ & $122(93.8)$ & $88(61.5)$ & $77(58)$ & $.001 *$ \\
\hline $4-$ Injectable drug addicts & $105(80.8)$ & $2(1.4)$ & $5(4)$ & $.001 *$ \\
\hline \multicolumn{5}{|l|}{ Symptoms of HCV: } \\
\hline $1-$ Fever and abdominal pain & $103(79.2)$ & $81(56.6)$ & $71(54.2)$ & $.001 *$ \\
\hline 2-Vomiting and loss of appetite & $106(81.5)$ & $82(57.3)$ & $70(52.7)$ & $.001 *$ \\
\hline $3-$ Dark urine and light stools & $90(69.2)$ & $71(49.7)$ & $58(43.9)$ & $.002 *$ \\
\hline $4-$ Yellowish skin (Jaundice) & $118(90.8)$ & $115(80.4)$ & $103(77.5)$ & $.046^{*}$ \\
\hline
\end{tabular}

(*) significant $(\mathrm{p}<0.05)$ 
Table 3:Comparison between Physicians, Nurses and Traditional Providers Regarding their Correct Knowledge about Modes of Transmission and Prevention of HCV:

\begin{tabular}{|c|c|c|c|c|}
\hline & $\begin{array}{l}\text { Physicians } \\
(\mathrm{N}=130)\end{array}$ & $\begin{array}{l}\text { Nurses } \\
(\mathrm{N}=143)\end{array}$ & $\begin{array}{l}\text { Traditional } \\
\text { providers } \\
(\mathrm{N}=133)\end{array}$ & $\mathrm{x}^{2}$ \\
\hline Variable & N. $(\%)$ & N. $(\%)$ & N. $(\%)$ & $\mathrm{P}$ value \\
\hline \multicolumn{5}{|l|}{ Methods of HCV transmission: } \\
\hline 1 - Contaminated blood & $129(99.2)$ & $140(97.9)$ & $114(85.7)$ & $.001 *$ \\
\hline 2 - Toothbrushes and razors & $116(89.2)$ & $110(76.9)$ & $99(74.4)$ & .89 \\
\hline $3-$ Kissing or biting (saliva) & $77(59.6)$ & $67(46.9)$ & $28(20.8)$ & $.001 *$ \\
\hline $4-$ Suspicious sexual relations & $111(85.4)$ & $104(72.7)$ & $93(69.9)$ & $.001 *$ \\
\hline $\begin{array}{l}5 \text {-Renal dialysis, blood transfusion, } \\
\text { organ transplantion }\end{array}$ & $122(93.8)$ & $85(59.4)$ & $74(55.7)$ & $.039 *$ \\
\hline $6-$ From the mother to the fetus & $102(78.5)$ & $84(58.7)$ & $67(50.7)$ & $.001 *$ \\
\hline $1-$ Tooth extraction & $108(83.1)$ & $74(51.7)$ & $2(1.5)$ & $.001 *$ \\
\hline $2-$ Tooth filling & $96(73.8)$ & $68(47.6)$ & $2(1.5)$ & $.001 *$ \\
\hline 3 - Using contaminated instruments & $122(93.8)$ & $104(72.7)$ & $4(3)$ & $.001 *$ \\
\hline $4-$ Anesthetic injection & $107(82.3)$ & $69(48.3)$ & $0(0)$ & $.001 *$ \\
\hline 5 - Gum Treatment & $95(73.1)$ & $64(44.8)$ & $1(0.8)$ & $.001 *$ \\
\hline $\begin{array}{l}1-\text { Avoid sharing toothbrushes and } \\
\text { razors }\end{array}$ & $116(89.2)$ & $121(84.6)$ & $107(80.5)$ & .168 \\
\hline $2-$ Avoid sharing shaving equipment & $101(77.7)$ & $95(66.4)$ & $83(62.2)$ & $.028 *$ \\
\hline $\begin{array}{l}3 \text { - Following guidelines on blood } \\
\text { transfusion }\end{array}$ & $129(99.2)$ & $112(78.3)$ & $95(71.4)$ & $.001 *$ \\
\hline $\begin{array}{l}4-\text { Avoid } \\
\text { relationships }\end{array}$ & $111(85.4)$ & $83(58)$ & $69(51.7)$ & $.013 *$ \\
\hline $\begin{array}{l}\text { Importance of washing hands before } \\
\text { wearing gloves? }\end{array}$ & $115(88.5)$ & $125(87.6)$ & $115(86.5)$ & $.001 *$ \\
\hline $\begin{array}{l}\text { Importance of washing hands after } \\
\text { removing gloves? }\end{array}$ & $124(95.4)$ & $135(94.3)$ & $116(87.2)$ & $.001 *$ \\
\hline Importance of wearing the coat? & $118(90.8)$ & $128(89.3)$ & $92(69.2)$ & $.001 *$ \\
\hline $\begin{array}{l}\text { Importance of following guidelines } \\
\text { after any skin cut (such as washing } \\
\text { the wound with water)? }\end{array}$ & $130(100)$ & $142(99.3)$ & $121(91)$ & $.004 *$ \\
\hline $\begin{array}{l}\text { Importance of using sterilized } \\
\text { instruments for every patient? }\end{array}$ & $130(100)$ & $142(99.3)$ & $122(91.7)$ & $.002 *$ \\
\hline $\begin{array}{l}\text { Importance of using safety boxes to } \\
\text { get rid of sharp objects? }\end{array}$ & $130(100)$ & $143(100)$ & $109(82)$ & $.001 *$ \\
\hline $\begin{array}{l}\text { Importance of using plastic bags to } \\
\text { get rid of other waste? }\end{array}$ & $126(96.9)$ & $129(90.2)$ & $113(85)$ & $.011 *$ \\
\hline $\begin{array}{l}\text { Importance of using specific way to } \\
\text { deal with sterilized instruments? }\end{array}$ & $129(99.2)$ & $142(99.3)$ & $122(91.7)$ & $.0003^{*}$ \\
\hline $\begin{array}{l}\text { Importance of availability of mask } \\
\text { and sterilization instruments? }\end{array}$ & $128(98.5)$ & $139(97.3)$ & $111(83.5)$ & $.001 *$ \\
\hline
\end{tabular}

(*) significant $(\mathrm{p}<0.05)$ 
Table 4: Comparison between Physicians and Nurses according to their Correct Practice using the Observational Checklist

\begin{tabular}{|l|l|l|l|}
\hline & $\begin{array}{l}\text { Physicians } \\
(\mathbf{N = 1 3 0 )}\end{array}$ & $\begin{array}{l}\text { Nurses } \\
(\mathbf{N = 1 4 3 )}\end{array}$ & $\mathbf{x}^{\mathbf{2}}$ \\
\hline Variable & $\mathbf{N ~ ( \% )}$ & $\mathbf{N ~ ( \% )}$ & $\begin{array}{l}\mathbf{P} \\
\text { value }\end{array}$ \\
\hline Washing hands before wearing gloves & $72(55.3)$ & $60(42.2)$ & $.02^{*}$ \\
\hline Washing hands after removeing gloves & $82(63.1)$ & $68(47.8)$ & $.010^{*}$ \\
\hline Wearing gloves when dealing with patient & $94(72)$ & $78(54.5)$ & $.002^{*}$ \\
\hline Change gloves after each patient & $98(75.2)$ & $63(56.1)$ & $.001^{*}$ \\
\hline Wearing the coat & $75(57.7)$ & $69(48.3)$ & .100 \\
\hline Use safety boxes for sharps & $76(58)$ & $70(49.2)$ & .120 \\
\hline Use plastic bags for waste disposal & $77(59.2)$ & $61(42.7)$ & $.009^{*}$ \\
\hline
\end{tabular}

(*) significant $(\mathrm{p}<0.05)$

Table 5: Knowledge and Practice Scores Physicians, Nurses and Traditional Health Care Providers

\begin{tabular}{|l|l|l|l|}
\hline & $\begin{array}{l}\text { Physicians } \\
(\mathbf{1 3 0})\end{array}$ & $\begin{array}{l}\text { Nurses } \\
\mathbf{( 1 4 3 )}\end{array}$ & $\begin{array}{l}\text { Traditional } \\
\text { providers(133) }\end{array}$ \\
\hline Variable & Mean \pm SD & Mean \pm SD & Mean \pm SD \\
\hline Knowledge score & $36.1 \pm 5.6$ & $29.6 \pm 6.2$ & $25.9 \pm 5.8$ \\
\hline Total knowledge score & 44 & 41 & 40 \\
\hline Practice score & $5.0 \pm 3.9$ & $3.49 \pm 3.5$ & \\
\hline Total practice score & 9 & 7 & \\
\hline Overall score & $41.1 \pm 7.8$ & $32.6 \pm 7.4$ & \\
\hline Total overall score & 53 & 48 & \\
\hline
\end{tabular}


Table 6: Association between the Participants' Knowledge Score and their Sociodemographic Characteristics

\begin{tabular}{|c|c|c|c|c|c|c|}
\hline \multirow[t]{2}{*}{ Variables } & \multicolumn{2}{|c|}{$\begin{array}{l}\text { Physicians' knowledge } \\
\text { score }\end{array}$} & \multicolumn{2}{|c|}{ Nurses' knowledge score } & \multicolumn{2}{|l|}{$\begin{array}{l}\text { Traditional } \\
\text { knowledge score }\end{array}$} \\
\hline & Mean \pm SD & P value & Mean \pm SD & $P$ value & Mean \pm SD & $P$ value \\
\hline Age & $(34 \pm 9.4)$ & $0.02 *$ & $(33 \pm 10)$ & $0.002^{*}$ & $(38.5 \pm 6.8)$ & $0.04 *$ \\
\hline \multirow[t]{2}{*}{ Gender } & Male $(35.9 \pm 5.8)$ & \multirow{2}{*}{$0.3^{* *}$} & Male $(33.3 \pm 5.6)$ & \multirow{2}{*}{$0.15^{* *}$} & $(24 \pm 6)$ & \multirow{2}{*}{$0.04 * *$} \\
\hline & Female (36.5 \pm 4.9$)$ & & Female $(29.4 \pm 6)$ & & $(26.7 \pm 5.6)$ & \\
\hline \multirow[t]{6}{*}{ Residence } & Cairo $\quad(38.6 \pm 3.6)$ & \multirow[t]{6}{*}{$0.001 * * *$} & Cairo $(28.1 \pm 6.8)$ & \multirow[t]{6}{*}{$0.001 * * *$} & $(27.6 \pm 4.3)$ & \multirow[t]{6}{*}{$0.07 * * *$} \\
\hline & Dakahlia $(34.2 \pm 5)$ & & Dakahlia $(30.8 \pm 3.1)$ & & $\begin{array}{ll}\text { Dakahlia } & (25.3 \pm 5.2)\end{array}$ & \\
\hline & Gharbia (36.6 \pm 4.6$)$ & & Gharbia $(32.7 \pm 6.5)$ & & $(24.4 \pm 6.6)$ & \\
\hline & Assuit $(39.6 \pm 2.6)$ & & Assuit $\quad(31 \pm 2)$ & & $(28 \pm 4.3)$ & \\
\hline & Beniseuf(30.2 \pm 7.4$)$ & & Beniseuf $(25.2 \pm 6.4)$ & & Beni-seuf $\quad(24.7 \pm 7.1)$ & \\
\hline & Red sea $(33.9 \pm 4.6)$ & & Red sea $\quad(30.1 \pm 6)$ & & $(24.5 \pm 2.12)$ & \\
\hline \multirow{3}{*}{$\begin{array}{l}\text { Experience } \\
\text { in years }\end{array}$} & $<1$ year $(32.1 \pm 6.6)$ & \multirow[t]{3}{*}{$0.027 * * *$} & $<1$ year $(28.5 \pm 6.2)$ & \multirow[t]{3}{*}{$0.017 * * *$} & $(24.4 \pm 4.7)$ & \multirow[t]{3}{*}{$0.001^{* * *}$} \\
\hline & 1-5years $(35.2 \pm 4.9)$ & & $1-5$ years $(31.8 \pm 5.6)$ & & $1-5$ years $\quad(24.9 \pm 5)$ & \\
\hline & $>5$ years $(36.4 \pm 5.8)$ & & $>5$ years $(32.2 \pm 4.3)$ & & $(27.5 \pm 3.1)$ & \\
\hline \multirow{2}{*}{$\begin{array}{l}\text { Attend } \\
\text { infection } \\
\text { control } \\
\text { course }\end{array}$} & Yes $\quad(37.6 \pm 5.6)$ & \multirow[t]{2}{*}{$0.026^{* *}$} & $(29.9 \pm 6.1)$ & \multirow[t]{2}{*}{$0.021 * *$} & & \\
\hline & No $\quad(35.1 \pm 5.3)$ & & $(27.3 \pm 6.3)$ & & & \\
\hline
\end{tabular}

* Correlation coefficient

** Student's t test for independent samples

*** ANOVA test 
Table 7: Association between the Participants' Practice Score and their Sociodemographic Characteristics

\begin{tabular}{|c|c|c|c|c|}
\hline \multirow{2}{*}{ Variable } & \multicolumn{2}{|c|}{ Physicians practice score } & \multicolumn{2}{|c|}{ Nurses practice score } \\
\hline & Mean \pm SD & P value & Mean \pm SD & P value \\
\hline \multirow[t]{2}{*}{ Gender } & Male $\quad(5.04 \pm 3.9)$ & \multirow[t]{2}{*}{$0.87 * *$} & Male $(3 \pm 3.9)$ & \multirow[t]{2}{*}{$0.76^{* *}$} \\
\hline & female $(5 \pm 4.09)$ & & Female $(3.5 \pm 3.5)$ & \\
\hline \multirow[t]{6}{*}{ Residence } & Cairo $\quad(5.4 \pm 4.1)$ & \multirow[t]{6}{*}{$0.001 * * *$} & Cairo $(4.3 \pm 3.9)$ & \multirow[t]{6}{*}{$0.003 * * *$} \\
\hline & Dakahlia(4.6 \pm 4.3$)$ & & Dakahlia(4.2 \pm 3.6$)$ & \\
\hline & Gharbia (3.6 \pm 3.2$)$ & & Gharbi $(1.4 \pm 1.1)$ & \\
\hline & Assuit $(8 \pm 1.6)$ & & Assuit $\quad(0.5 \pm 0.3)$ & \\
\hline & Beni-seuf(4 43.2$)$ & & Beniseuf(4.2 \pm 3.7$)$ & \\
\hline & Red sea $(3.7 \pm 3.1)$ & & Red sea(3.6 $6 \pm 3.4)$ & \\
\hline \multirow{3}{*}{$\begin{array}{l}\text { Experience in } \\
\text { years }\end{array}$} & $<$ 1year $(3.7 \pm 2.3)$ & \multirow[t]{3}{*}{$0.037 * * *$} & $<1$ year $(2.2 \pm 2)$ & \multirow[t]{3}{*}{$0.02 * * *$} \\
\hline & $1-5$ years $(5.1 \pm 2.7)$ & & $1-5 y e a r s(4.1 \pm 2.3)$ & \\
\hline & >5years $(5.6 \pm 2.5)$ & & $>5$ years $(4.5 \pm 2.4)$ & \\
\hline \multirow{2}{*}{$\begin{array}{l}\text { Attend } \\
\text { infection } \\
\text { control course }\end{array}$} & $(5.7 \pm 3.4)$ & \multirow[t]{2}{*}{$0.001 * *$} & $(2.3 \pm 2.1)$ & \multirow[t]{2}{*}{$0.001 * *$} \\
\hline & $(3.2 \pm 3)$ & & $(4.2 \pm 3)$ & \\
\hline
\end{tabular}

** Mann-Whitney test for comparing non parametric two independent samples *** Kruskal- Wallis test for comparing more than two non parametric independent samples 